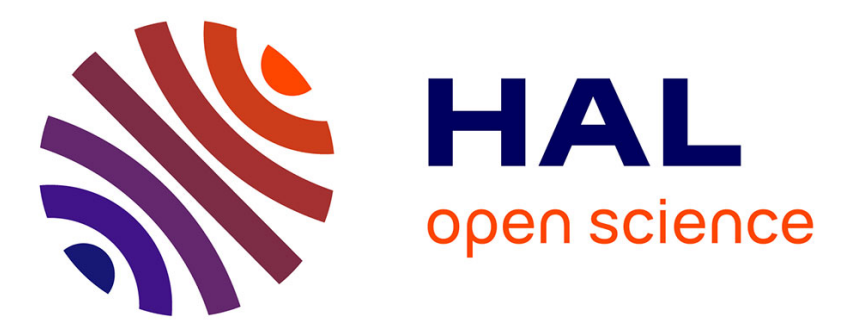

\title{
Oxygen storage capacity measurements of three-way catalysts under transient conditions
}

C. Descorme, Rachida Taha, Najat Mouaddib-Moral, Daniel Duprez

\section{To cite this version:}

C. Descorme, Rachida Taha, Najat Mouaddib-Moral, Daniel Duprez. Oxygen storage capacity measurements of three-way catalysts under transient conditions. Applied Catalysis A : General, 2002, 223

(1-2), pp.287-299. 10.1016/s0926-860x(01)00765-7 . hal-01400710

\section{HAL Id: hal-01400710 \\ https://hal.science/hal-01400710}

Submitted on 8 Oct 2021

HAL is a multi-disciplinary open access archive for the deposit and dissemination of scientific research documents, whether they are published or not. The documents may come from teaching and research institutions in France or abroad, or from public or private research centers.
L'archive ouverte pluridisciplinaire HAL, est destinée au dépôt et à la diffusion de documents scientifiques de niveau recherche, publiés ou non, émanant des établissements d'enseignement et de recherche français ou étrangers, des laboratoires publics ou privés.

\section{(c)(1)}

Distributed under a Creative Commons Attribution| 4.0 International License 


\title{
Oxygen storage capacity measurements of three-way catalysts under transient conditions
}

\author{
Claude Descorme ${ }^{\mathrm{a}, *}$, Rachid Taha ${ }^{\mathrm{a}}$, Najat Mouaddib-Moral ${ }^{\mathrm{b}}$, Daniel Duprez $^{\mathrm{a}}$ \\ ${ }^{a}$ Laboratoire de Catalyse en Chimie Organique (LACCO) - UMR CNRS 6503, Université de Poitiers, \\ 40 avenue du Recteur Pineau, F-86022 Poitiers Cedex, France \\ ${ }^{\mathrm{b}}$ Renault Automobiles, Centre Technique de Lardy, 1 Allée de Cornuel, 91510 Lardy, France
}

\begin{abstract}
Oxygen storage capacity (OSC) measurements at $450^{\circ} \mathrm{C}$ were carried out on 10 different alumina and ceria-alumina supported $\mathrm{Pd}, \mathrm{Pt}, \mathrm{Rh}, \mathrm{PdRh}$ and $\mathrm{PtRh}$ catalysts. Experiments were performed under both transient $(0.5 \mathrm{and} 1 \mathrm{~Hz})$ and stationary reaction conditions using a mass spectrometer for the gas phase analysis every $100 \mathrm{~ms}$. OSC was shown to be strongly dependent on the metal nature - oxidized or reduced. Rh appeared to be the best OSC promoter. Furthermore, ceria addition to the alumina support strongly enhances the OSC. In fact looking at the OSC values, a factor of 3 was evidenced between $\mathrm{Pt} / \mathrm{Al}_{2} \mathrm{O}_{3}$ and $\mathrm{Rh} / \mathrm{Al}_{2} \mathrm{O}_{3}$ and an additional factor of about 12 between $\mathrm{Rh} / \mathrm{Al}_{2} \mathrm{O}_{3}$ and $\mathrm{Rh} / \mathrm{CeO}_{2}-\mathrm{Al}_{2} \mathrm{O}_{3}$. The metal oxides relative stability as well as the metal electronic configuration were shown to be strongly influent on the overall reactivity of the catalyst. Additional kinetic studies showed that the oxide reduction rate under $\mathrm{CO}$ is slower than the oxide oxidation rate under $\mathrm{O}_{2}$. Finally a general scheme for the oxygen storage process is proposed and discussed.
\end{abstract}

Keywords: Oxygen storage; Transient conditions; Stationary conditions; Palladium; Platinum; Rhodium; Catalyst; Alumina; Ceria-alumina

\section{Introduction}

In the field of three-way catalysis (TWC), oxygen storage is a crucial point. As a result, lots of studies have been devoted to oxygen storage capacity (OSC) measurements [1-9]. The performances of automotive pollution control catalysts have been shown to somehow correlates with the OSC of these solids. In fact, the OSC measurement has been considered as a potential indication of the catalyst state - active or inactive - for on-board diagnostic (OBD) applications [10-14]. However, up to now, OSC measurements have been carried out under ideal conditions, in a

\footnotetext{
* Corresponding author. Tel.: +33-5-49-45-39-97; fax: +33-5-49-45-34-99.

E-mail address: claude.descorme@univ-poitiers.fr (C. Descorme).
}

continuous mode [1,7]. Such measurement conditions are far from real post-combustion operating conditions, when the exhaust gas composition rapidly oscillates between hydrocarbon-rich and hydrocarbon-poor mixtures.

This paper deals with the development of a new OSC measurement technique. OSC could be measured in a transient regime by injection of alternate $\mathrm{CO}$ or $\mathrm{O}_{2}$ pulses every 1 or $2 \mathrm{~s}(F=1$ or $0.5 \mathrm{~Hz})$. Such measurements conditions were shown to be appropriate to simulate the fluctuations in the real exhaust gas composition.

This technique was applied to the study of two series of Pt-, Rh- and Pd-based model three-way catalysts. Our study will concentrate on both the effect of ceria on the OSC and the influence of the nature of the noble metal on the $\mathrm{CO}$ oxidation catalytic reaction. 


\section{Experimental}

\subsection{Catalysts preparation}

Alumina support (A) was obtained from $\gamma$-alumina $\left(100 \mathrm{~m}^{2} \mathrm{~g}^{-1}\right)$ directly supplied by Institut Français du Pétrole (IFP, France). After treatment at $900^{\circ} \mathrm{C}$, the $\delta-\mathrm{Al}_{2} \mathrm{O}_{3}$ phase is predominant.

A $12 \% \mathrm{CeO}_{2}-\mathrm{Al}_{2} \mathrm{O}_{3}$ support (CA) was prepared by impregnation of the alumina support with an aqueous solution of an ammonium and cerium nitrate $\left(\mathrm{Ce}\left(\mathrm{NH}_{4}\right)_{2}\left(\mathrm{NO}_{3}\right)_{6}\right)$. After evaporation and drying, the $\mathrm{CeO}_{2}-\mathrm{Al}_{2} \mathrm{O}_{3}$ support is calcined at $450^{\circ} \mathrm{C}$ for $5 \mathrm{~h}$.

Monometallic catalysts were prepared by incipient wetness impregnation of the support either with an aqueous solution of diaminodinitro platinum(II) $\left(\mathrm{Pt}\left(\mathrm{NH}_{3}\right)_{2}\left(\mathrm{NO}_{2}\right)_{2}\right)$ or with a solution of palladium(II) diacetylacetonate $\left(\mathrm{Pd}\left(\mathrm{C}_{5} \mathrm{H}_{7} \mathrm{O}_{2}\right)_{2}\right)$ in acetone. Bimetallic catalysts were subsequently prepared by impregnation of the pre-reduced monometallic catalyst with an aqueous solution of $\mathrm{Rh}^{3+}\left(\mathrm{Rh}\left(\mathrm{NO}_{3}\right)_{3}\right)$. Every metal precursor was chlorine-free. In fact, chlorine was found to decrease both oxygen mobility at the oxides surface and the OSC [15-18]. Such an effect of chlorine could result in an inhibition of the oxygen storage.

After impregnation Pt-based (series 1) and Pd-based (series 2) catalysts were dried and further calcined at $350^{\circ} \mathrm{C}$ [19]. Every catalyst was further aged under $10 \% \mathrm{H}_{2} \mathrm{O}+1 \% \mathrm{O}_{2}$ at $900^{\circ} \mathrm{C}$ for $2 \mathrm{~h} \mathrm{[20].} \mathrm{In} \mathrm{fact,}$ fresh catalysts were too active so that oxygen storage kinetics could not be accessed.

The composition of the catalysts is, respectively, given in Tables 1 and 2 for series 1 and 2 samples.

Table 1

Metal loading for the different bimetallic PtRh-based alumina (A) and ceria-alumina (CA) supported catalysts (series 1)

\begin{tabular}{llll}
\hline Catalyst & wt.\% & & $\begin{array}{l}\mu \text { mol of metal atoms } \\
\text { per gram of catalyst }\end{array}$ \\
\cline { 2 - 3 } & $\mathrm{Pt}$ & $\mathrm{Rh}$ & \\
\hline PtA & 1.17 & 0.00 & 60 \\
PtCA & 1.00 & 0.00 & 51.3 \\
PtRhA $^{\mathrm{a}}$ & 0.70 & 0.21 & 55.3 \\
PtRhCA $^{\mathrm{a}}$ & 0.60 & 0.21 & 51.2 \\
RhA & 0.00 & 0.50 & 49.5 \\
RhCA & 0.00 & 0.53 & 51.4 \\
\hline
\end{tabular}

\footnotetext{
${ }^{\text {a }}$ The metallic phase consist in $35 \% \mathrm{Rh}$ and $65 \% \mathrm{Pt}$ or $\mathrm{Pd}$.
}

Table 2

Metal loading for the different bimetallic PdRh-based alumina (A) and ceria-alumina (CA) supported catalysts (series 2)

\begin{tabular}{llll}
\hline Catalyst & wt.\% & & $\begin{array}{l}\mu \text { mol of metal atoms } \\
\text { per gram of catalyst }\end{array}$ \\
\cline { 2 - 3 } & Pd & $\mathrm{Rh}$ & \\
\hline PdA & 0.50 & 0.00 & 47 \\
PdCA & 0.50 & 0.00 & 47 \\
PdRhA $^{\text {a }}$ & 0.33 & 0.17 & 47 \\
PdRhCA $^{\text {a }}$ & 0.33 & 0.17 & 47 \\
RhA & 0.00 & 0.50 & 49.5 \\
RhCA & 0.00 & 0.53 & 51.4 \\
\hline
\end{tabular}

${ }^{\mathrm{a}}$ The metallic phase consist in $35 \% \mathrm{Rh}$ and $65 \% \mathrm{Pt}$ or $\mathrm{Pd}$.

The composition of the metallic phase was adjusted so that every catalyst contains about $50 \mu \mathrm{mol}$ of metal atoms per gram of catalyst.

\subsection{Experimental setup}

The apparatus used for this set of experiments is dedicated to the study of reactions $-\mathrm{CO}+\mathrm{O}_{2}$ in our case - carried out under transient conditions at any given frequency lower than $1 \mathrm{~Hz}$. This system consists in two parts: the gas manifold and the mass spectrometer.

Reactants $\left(\mathrm{CO}\right.$ and $\left.\mathrm{O}_{2}\right)$ flows are regulated using mass flow controllers. Before the reactor entrance, reactants are mixed with a $1 \% \mathrm{Ar}$ in $\mathrm{He}$ carrier gas $\left(100 \mathrm{~cm}^{3} \mathrm{~min}^{-1}\right)$. Any kind of $\mathrm{CO} /(1 \% \mathrm{Ar}+\mathrm{He})$ and $\mathrm{O}_{2} /(1 \% \mathrm{Ar}+\mathrm{He})$ mixtures could be obtained. For this study, $2 \% \mathrm{CO}$ and $1 \% \mathrm{O}_{2}$ mixtures were used. Reactant injections were controlled using automated injection valves. Alternate $\mathrm{CO}$ and $\mathrm{O}_{2}$ injections may take place at a frequency as high as $1 \mathrm{~Hz}$. To optimize the response time, the dead volume was reduce to less than $2.5 \mathrm{~cm}^{3}$, including the whole reaction circuit from the automated valve up to the capillary tube before the mass spectrometer.

A $2 \mathrm{mg}$ sample, diluted in $18 \mathrm{mg}$ cordierite, is placed in a straight Pyrex reactor and pretreated under pure helium at $450^{\circ} \mathrm{C}$ (ramp rate: $2^{\circ} \mathrm{C} \mathrm{min}^{-1}$ ) for $15 \mathrm{~min}$. Reactions are carried out at $450^{\circ} \mathrm{C}$. Despite of the low sample weight, reproducibility was checked to be better than $5 \%$.

The experiment consists in five different steps, as presented in Fig. 1 - (i) OSC measurement at $450^{\circ} \mathrm{C}$ under transient conditions: alternate $2 \% \mathrm{CO}$ 


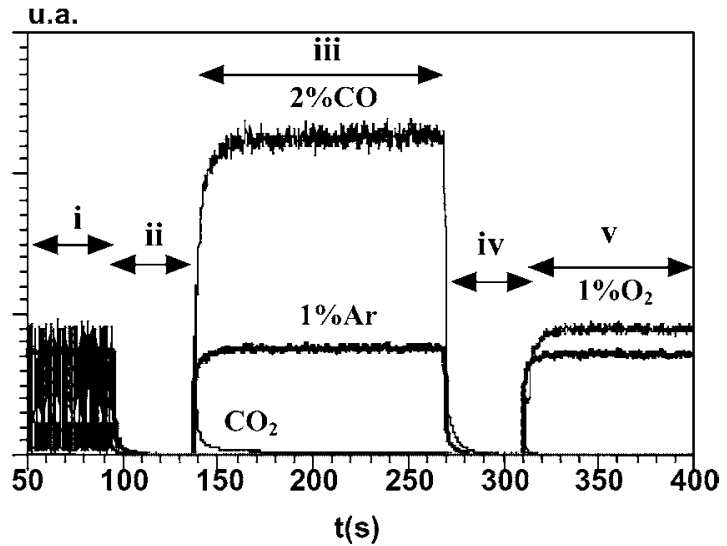

Fig. 1. One typical experiment. General scheme for the measurement progression.

or $1 \% \mathrm{O}_{2}$ pulses at a frequency of 1 or $0.5 \mathrm{~Hz}$ for 10 min. Carrier gas is $1 \% \mathrm{Ar}$ in He. The last pulse is $\mathrm{O}_{2}$ : (ii) outgassing under pure $\mathrm{He}$ for $30 \mathrm{~s}$; (iii) step change from 0 to $2 \% \mathrm{CO}(2 \mathrm{~min})$ at $450^{\circ} \mathrm{C}$. Carrier gas is $1 \% \mathrm{Ar}$ in He. The Ar signal is used as a reference to deduced the dead volume of the reactor and to recalculate the inlet $\mathrm{CO}$ step change from 0 to 2\%: (iv) outgassing under pure $\mathrm{He}$ for $30 \mathrm{~s}$; (v) step change from 0 to $1 \% \mathrm{O}_{2}(2 \mathrm{~min})$ at $450^{\circ} \mathrm{C}$. Carrier gas is again $1 \% \mathrm{Ar}$ in He. The Ar signal is used as a reference.

The evolution of the gas phase composition is followed by mass spectrometry. Masses $m / e=4(\mathrm{He})$, $28(\mathrm{CO}), 32\left(\mathrm{O}_{2}\right), 44\left(\mathrm{CO}_{2}\right)$ and $40(\mathrm{Ar})$ are monitored every $0.1 \mathrm{~s}$. The global experimental setup used for both OSC measurements is schematized in Fig. 2.

All the results presented below will be expressed per gram of solid. Every sample consisted of $2 \mathrm{mg}$ catalyst plus $18 \mathrm{mg}$ cordierite for a total of $20 \mathrm{mg}$ of solid.

\section{Results and discussion}

\section{1. $\mathrm{CO}$ and $\mathrm{O}_{2}$ steps - stationary regime}

Data deduced from the second part of the OSC measurement being necessary for the interpretation of the results obtained in the first part, the results drawn from the second part of the experiment will be described first for a better readability of our manuscript.
In that second part of the experiment, OSC measurements are carried out at $450^{\circ} \mathrm{C}$ under "stationary" conditions. All samples are subsequently submitted to a 2 min long $2 \%$ CO step (step (iii), see Fig. 1) and a 2 min long $1 \% \mathrm{O}_{2}$ step (step (v), see Fig. 1) with intermediate outgassing under pure $\mathrm{He}$ for $10 \mathrm{~min}$. Evolutions of the unconverted $\mathrm{CO}$ and the produced $\mathrm{CO}_{2}$ during step (iii) (see Fig. 1) and the unconverted $\mathrm{O}_{2}$ during step (v) (see Fig. 1) are monitored as a function of time. Examples are given in Figs. 3 and 4 for Pd-based (series 2) and Pt-based (series 1) catalysts, respectively. The amounts of $\mathrm{CO}$ and $\mathrm{O}_{2}$ or $\mathrm{CO}_{2}$, respectively, consumed or produced were expressed as differential amounts of molecules consumed or produced per gram of solid and per unit time $\left(\mu \mathrm{mol} \mathrm{g}^{-1} \Delta t^{-1}\right)$. Differential calculations were performed using $0.1 \mathrm{~s}$ time increments. Every points on the curves correspond to the amount of $\mathrm{CO}, \mathrm{CO}_{2}$ or $\mathrm{O}_{2}$ consumed or produced during the last $0.1 \mathrm{~s}$. Cumulated amounts of $\mathrm{CO}$ and $\mathrm{O}_{2}$ consumption and $\mathrm{CO}_{2}$ production could be derived from the integration of these $\mathrm{CO}, \mathrm{CO}_{2}$ and $\mathrm{O}_{2}$ curves. An example is given in Fig. 5 for Pt-based catalysts (series 1).

Table 3 summarizes the amounts of $\mathrm{CO}$ consumed and $\mathrm{CO}_{2}$ produced during $\mathrm{CO}$ step and the amounts of $\mathrm{O}_{2}$ consumed during $\mathrm{O}_{2}$ step at time $t$ equals $0.5,1,5$ and $40 \mathrm{~s}$ for all 10 catalysts under study. A close look to this table shows that alumina-supported catalysts have a very low OSC. On the opposite, ceria-containing catalysts have the highest activity towards oxygen storage. These catalysts may be classified in descending order as follows: $\mathrm{Rh} / \mathrm{CeO}_{2}-\mathrm{Al}_{2} \mathrm{O}_{3}(\mathrm{RhCA})>\mathrm{PtRh} / \mathrm{CeO}_{2}-\mathrm{Al}_{2} \mathrm{O}_{3}$ $(\mathrm{PtRhCA})>\mathrm{PdRh} / \mathrm{CeO}_{2}-\mathrm{Al}_{2} \mathrm{O}_{3}(\mathrm{PdRhCA})>$ $\mathrm{Pd} / \mathrm{CeO}_{2}-\mathrm{Al}_{2} \mathrm{O}_{3}(\mathrm{PdCA})>\mathrm{Pt} / \mathrm{CeO}_{2}-\mathrm{Al}_{2} \mathrm{O}_{3}(\mathrm{PtCA})>$ $\mathrm{Rh} / \mathrm{Al}_{2} \mathrm{O}_{3}(\mathrm{RhA}) \cong \mathrm{PtRh} / \mathrm{Al}_{2} \mathrm{O}_{3}(\mathrm{PtRhA})>\mathrm{PdRh} /$ $\mathrm{Al}_{2} \mathrm{O}_{3}(\mathrm{PdRhA})>\mathrm{Pt} / \mathrm{Al}_{2} \mathrm{O}_{3}(\mathrm{PtA}) \cong \mathrm{Pd} / \mathrm{Al}_{2} \mathrm{O}_{3}$ $(\mathrm{PdA})$. Differences in OSC among these "aged" catalysts could be explained by the different sintering modes for Rh, Pt and Pd [21-23]. Furthermore, this reactivity ordering may be explained by the presence of both Rh and ceria. Rhodium strongly enhance the reducibility of ceria so that the OSC is greatly improved.

Furthermore, one can see that $\mathrm{PtRh} / \mathrm{CeO}_{2}-\mathrm{Al}_{2} \mathrm{O}_{3}$ (PtRhCA) behaves like a pure rhodium catalyst. This would indicate that (i) either Pt and Rh particles are distinct and $\mathrm{Rh}$ particles are in direct 


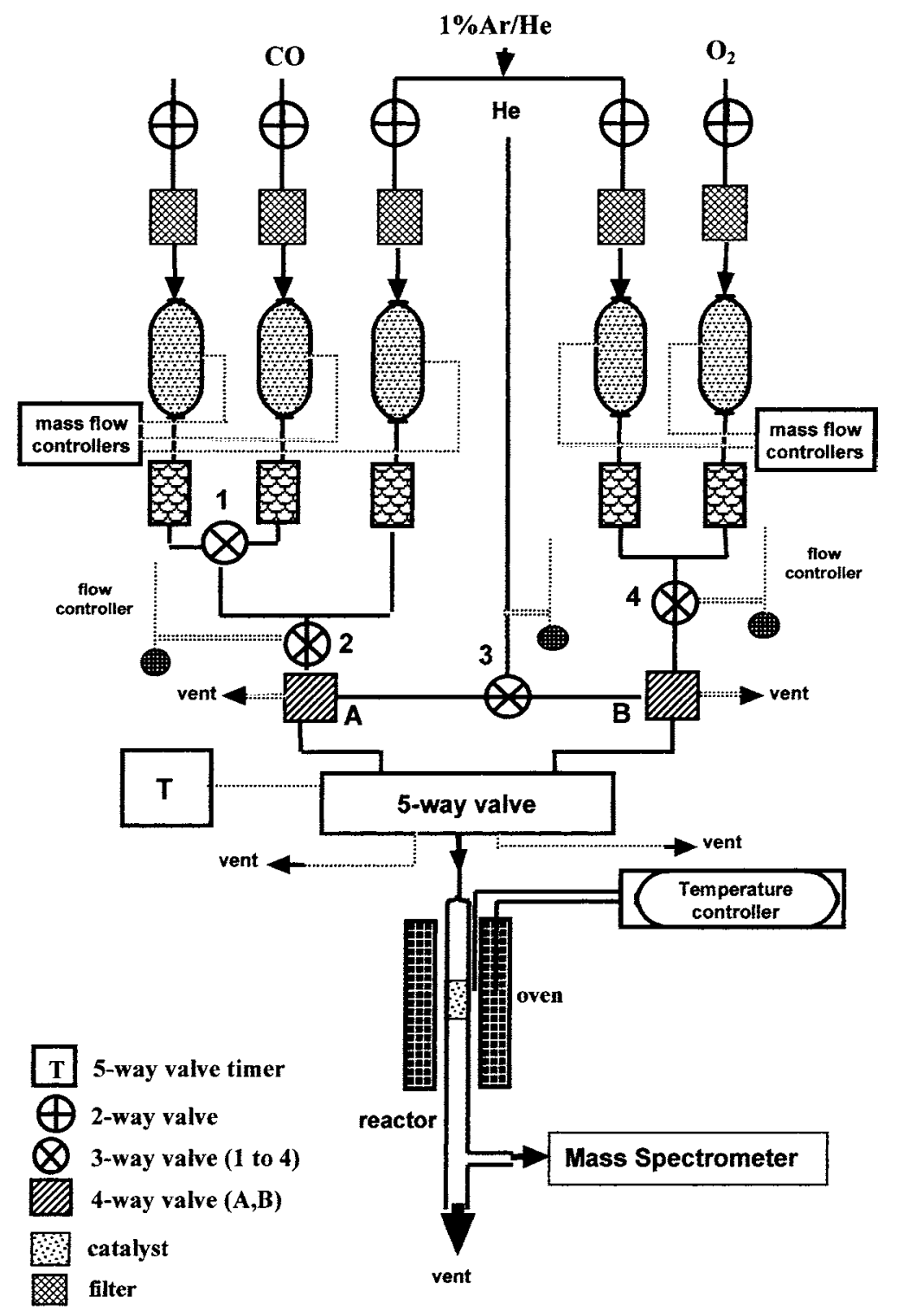

Fig. 2. Flow-sheet of the homemade apparatus used for OSC measurements.

interaction with ceria or (ii) $\mathrm{Rh}$ segregates at the surface of PtRh bimetallic particles. On the opposite, $\mathrm{PdRh} / \mathrm{CeO}_{2}-\mathrm{Al}_{2} \mathrm{O}_{3}$ (PdRhCA) reacts as pure $\mathrm{Pd}$ and we concluded that (i) either $\mathrm{Pd}$ and $\mathrm{Rh}$ particles are distinct and $\mathrm{Rh}$ particles do not interact with ceria or (ii) Pd segregates at the surface of PdRh bimetallic particles. In one case almost pure rhodium is the active surface and OSC is high, in the second case almost pure palladium is the active surface and OSC is low.

Finally, initial rates for $\mathrm{CO}$ consumption and $\mathrm{CO}_{2}$ formation upon $\mathrm{CO}$ step and for $\mathrm{O}_{2}$ consumption upon $\mathrm{O}_{2}$ step are reported in Fig. 6 for both alumina (A) and ceria-alumina (CA) supported catalysts. Initial rates 
$\mu \mathrm{mol}$ CO consumed $\cdot \mathrm{g}^{-1}$ solid.$\Delta \mathrm{t}^{-1}$

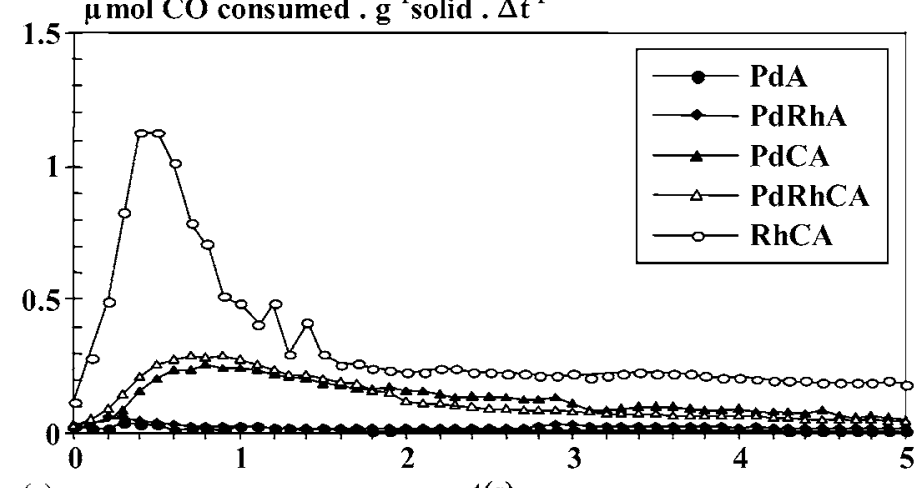

(a)

$t(s)$

$\mu \mathrm{mol} \mathrm{CO}_{2}$ produced. $\mathrm{g}^{-1}$ solid.$\Delta \mathrm{t}^{-1}$

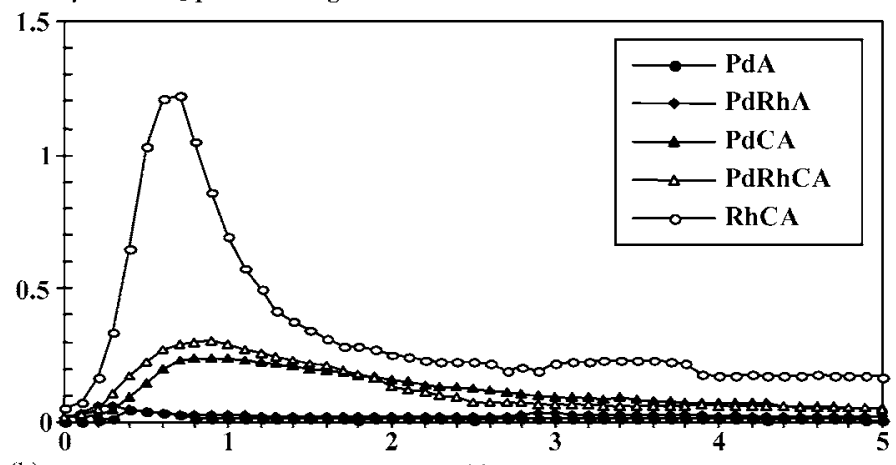

(b)

$\mathrm{t}(\mathrm{s})$

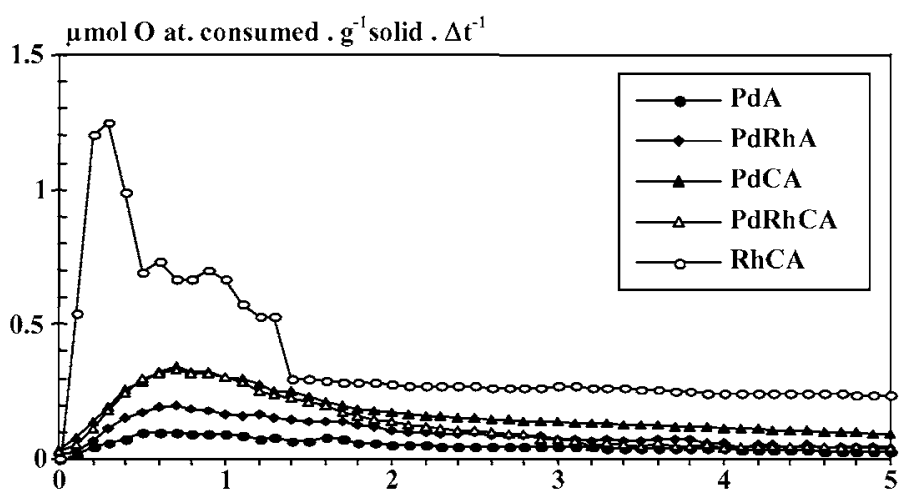

(c)

$\mathbf{t}(\mathbf{s})$

Fig. 3. $\mathrm{CO}$ and $\mathrm{O}_{2}$ step changes on pre-oxidized on bimetallic PdRh-based alumina (A) and ceria-alumina (CA) supported catalysts at $450^{\circ} \mathrm{C}$ : (a) differential $\mathrm{CO}$ consumption during $\mathrm{CO}$ step; (b) differential $\mathrm{CO}_{2}$ formation during $\mathrm{CO}$ step; (c) differential $\mathrm{O}_{2}$ consumption during $\mathrm{O}_{2}$ step expressed in $\mu \mathrm{molg}^{-1} \Delta t^{-1}(\Delta t=0.1 \mathrm{~s})$. 
$\mu \mathrm{mol}$ CO consumed $\cdot \mathrm{g}^{-1}$ solid.$\Delta \mathrm{t}^{-1}$
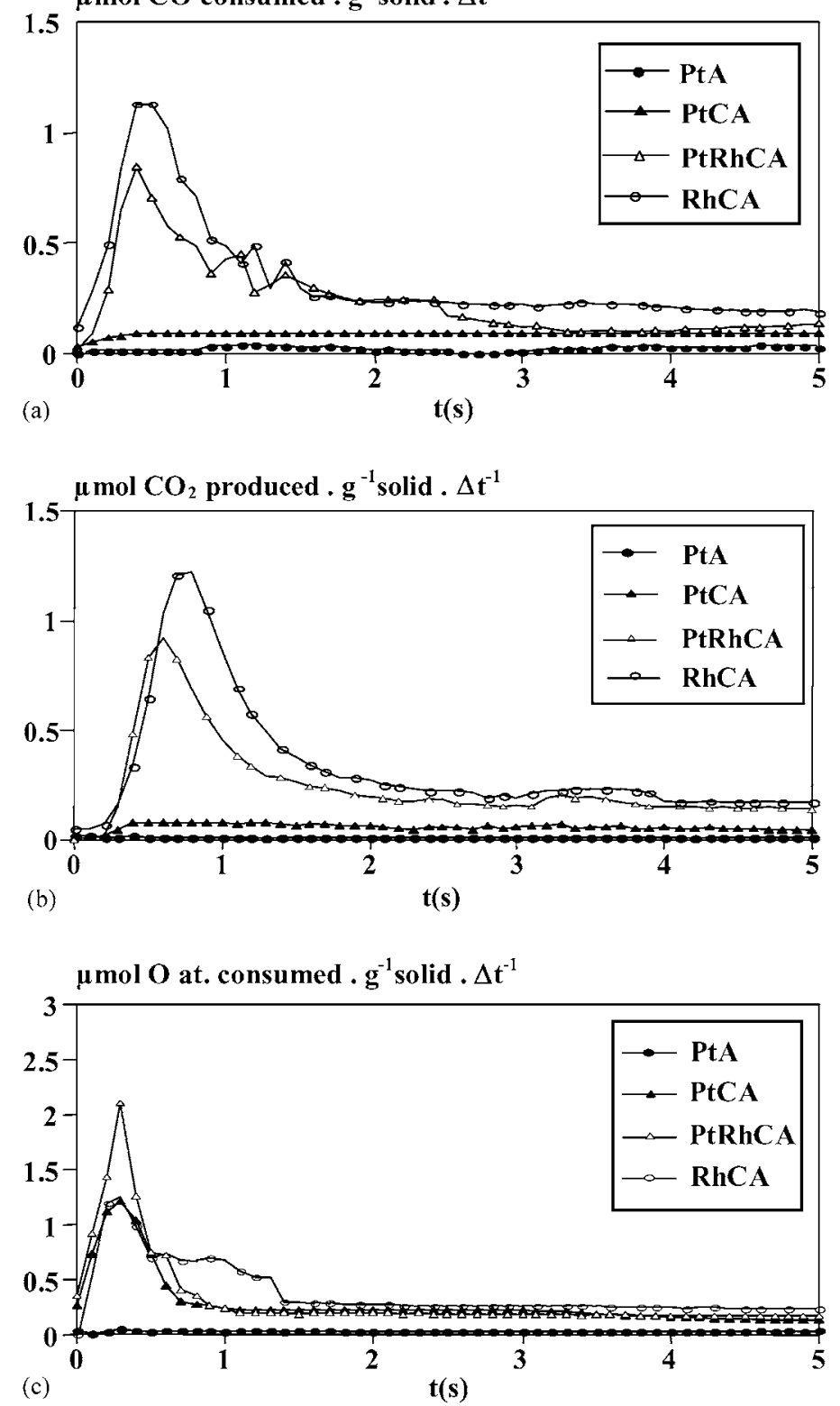

Fig. 4. $\mathrm{CO}$ and $\mathrm{O}_{2}$ step changes on pre-oxidized on bimetallic PtRh-based alumina (A) and ceria-alumina (CA) supported catalysts at $450^{\circ} \mathrm{C}$ : (a) differential $\mathrm{CO}$ consumption during $\mathrm{CO}$ step; (b) differential $\mathrm{CO}_{2}$ formation during $\mathrm{CO}$ step; (c) differential $\mathrm{O}_{2}$ consumption during $\mathrm{O}_{2}$ step expressed in $\mu \mathrm{molg}^{-1} \Delta t^{-1}(\Delta t=0.1 \mathrm{~s})$.

were deduced from the slopes, extrapolated at zero time, of the plots presented in Fig. 5. One may immediately conclude that reoxidation of the catalysts by molecular oxygen is much faster than the reduction under $\mathrm{CO}$.

\subsection{High frequency alternate $\mathrm{CO}$ and $\mathrm{O}_{2}$ pulses - transient regime}

As stated in Section 2, every experiment starts with the $\mathrm{OSC}$ measurement at $450^{\circ} \mathrm{C}$ under transient 

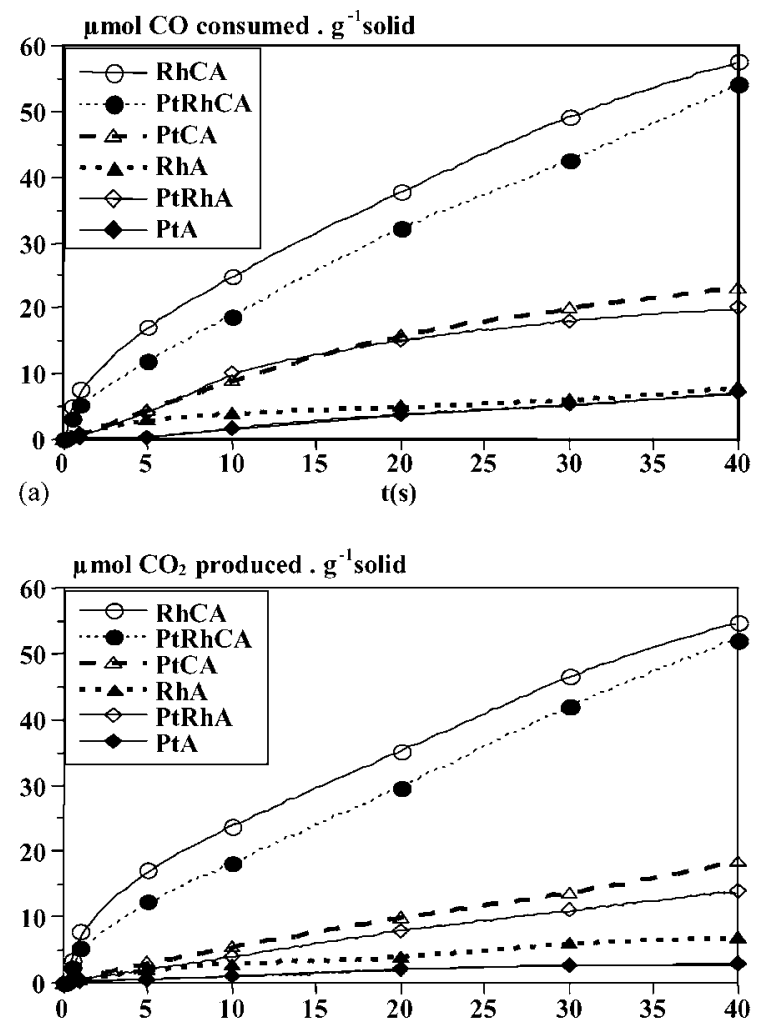

(b)

t(s)

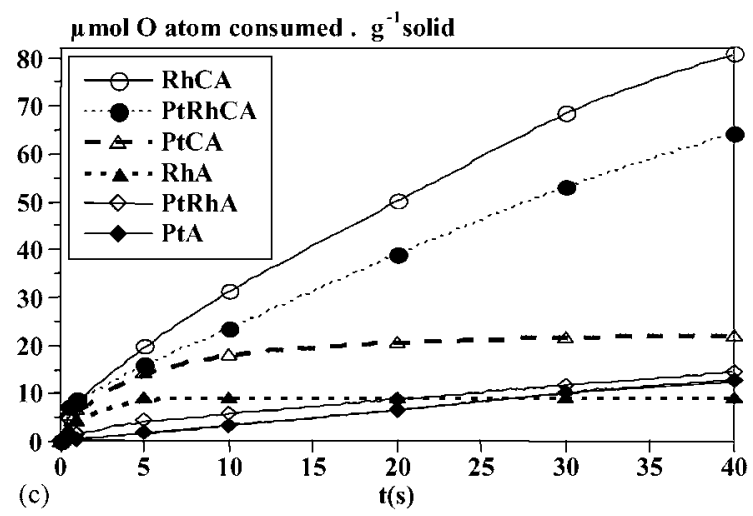

Fig. 5. Cumulative curves for $\mathrm{CO}$ consumption and $\mathrm{CO}_{2}$ formation during $\mathrm{CO}$ step and for $\mathrm{O}_{2}$ consumption during $\mathrm{O}_{2}$ step on bimetallic PtRh-based alumina (A) and ceria-alumina (CA) supported catalysts at $450^{\circ} \mathrm{C}$. Curves were built from points acquired every $0.1 \mathrm{~s}$. For sake of clarity, only a few experimental points are displayed.
Table 3

$\mathrm{CO}$ and $\mathrm{O}_{2}$ steps ${ }^{\mathrm{a}}$

\begin{tabular}{lllll}
\hline & $Q_{0.5}$ & $Q_{1}$ & $Q_{5}$ & $Q_{40}$ \\
\hline $\mathrm{PdA}$ & & & & \\
$\mathrm{CO}^{\mathrm{b}}$ & 0.2 & 0.3 & 0.7 & 3.9 \\
$\mathrm{CO}_{2}{ }^{\mathrm{b}}$ & 0.2 & 0.3 & 0.7 & 3.2 \\
$\mathrm{O}_{2}{ }^{\mathrm{c}}$ & 0.4 & 0.9 & 2.7 & 4.4
\end{tabular}

PtA

$\begin{array}{llllr}\mathrm{CO}^{\mathrm{b}} & 0.1 & 0.3 & 0.3 & 7 \\ \mathrm{CO}_{2}{ }^{\mathrm{b}} & 0.1 & 0.2 & 0.6 & 3 \\ \mathrm{O}_{2}{ }^{\mathrm{c}} & 0.2 & 0.4 & 1.7 & 13\end{array}$

RhA

$\begin{array}{lllll}\mathrm{CO}^{\mathrm{b}} & 0.4 & 0.9 & 3.0 & 8 \\ \mathrm{CO}_{2}{ }^{\mathrm{b}} & 0.3 & 0.6 & 2.0 & 7 \\ \mathrm{O}_{2}{ }^{\mathrm{c}} & 2.4 & 4.2 & 9.1 & 9\end{array}$

PdRhA

$\begin{array}{lll}\mathrm{CO}^{\mathrm{b}} & 0.2 & 0.4\end{array}$

$\mathrm{CO}_{2}{ }^{\mathrm{b}} \quad 0.2$

0.4

0.4

$\mathrm{O}_{2}{ }^{\mathrm{c}}$

0.4

1.3

1.1

1.3

6.6

PtRhA

$\mathrm{CO}^{\mathrm{b}}$

$\mathrm{CO}_{2}{ }^{\mathrm{b}}$

0.4

0.3

0.7

$$
0.6
$$

$$
1.5
$$

4.0

2.0

4.2

$\mathrm{PdCA}$

$\mathrm{CO}^{\mathrm{b}}$

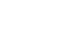

$\mathrm{CO}_{2}{ }^{\mathrm{b}}$

0.8

2.0

6.7

6.2

$\mathrm{O}_{2}{ }^{\mathrm{c}}$

0.8
1.3

1.7

8.7

20.1

PtCA

$\begin{array}{lllrl}\mathrm{CO}^{\mathrm{b}} & 0.5 & 0.8 & 4.5 & 23 \\ \mathrm{CO}_{2}{ }^{\mathrm{b}} & 0.3 & 0.7 & 3.1 & 19 \\ \mathrm{O}_{2}{ }^{\mathrm{c}} & 5.3 & 6.6 & 14.3 & 22\end{array}$

$\mathrm{RhCA}$

$\mathrm{CO}^{\mathrm{b}}$

$\mathrm{CO}_{2}{ }^{\mathrm{b}}$

4.9

7.8

7.9

$\mathrm{O}_{2}{ }^{\mathrm{c}}$

3.5

5.4

8.7

17.2

17.2

19.7

58

PdRhCA

$\mathrm{CO}^{\mathrm{b}}$

$\mathrm{CO}_{2}{ }^{\mathrm{b}}$

$$
1.3
$$

1.1

2.7

$$
2.6
$$

6.4

6.2

$\mathrm{O}_{2}{ }^{\mathrm{c}}$

1.2

2.8

6.5

11.9

PtRhCA

\begin{tabular}{lllll}
$\mathrm{CO}^{\mathrm{b}}$ & 3.1 & 5.4 & 12.0 & 54 \\
$\mathrm{CO}_{2}{ }^{\mathrm{b}}$ & 2.4 & 5.2 & 12.3 & 52 \\
$\mathrm{O}_{2}{ }^{\mathrm{c}}$ & 7.2 & 8.6 & 15.9 & 64 \\
\hline
\end{tabular}

a Cumulative amounts " $Q_{t}$ " $\left(\mu \mathrm{mol} \mathrm{g}{ }^{-1}\right)$ consumed or produced between zero time and time $t$ (s) on Pt, Pd, Rh, PtRh- and PdRhbased alumina (A) and ceria-alumina (CA) supported catalysts.

${ }^{\mathrm{b}} \mathrm{CO}$ consumed or $\mathrm{CO}_{2}$ formed $\left(\mu \mathrm{mol} \mathrm{g}^{-1}\right)$ after the $\mathrm{CO}$ step.

${ }^{\mathrm{c}} \mathrm{O}_{2}$ consumed ( $\mu \mathrm{mol} \mathrm{O}$ atoms $\mathrm{g}^{-1}$ ) after the $\mathrm{O}_{2}$ step. 

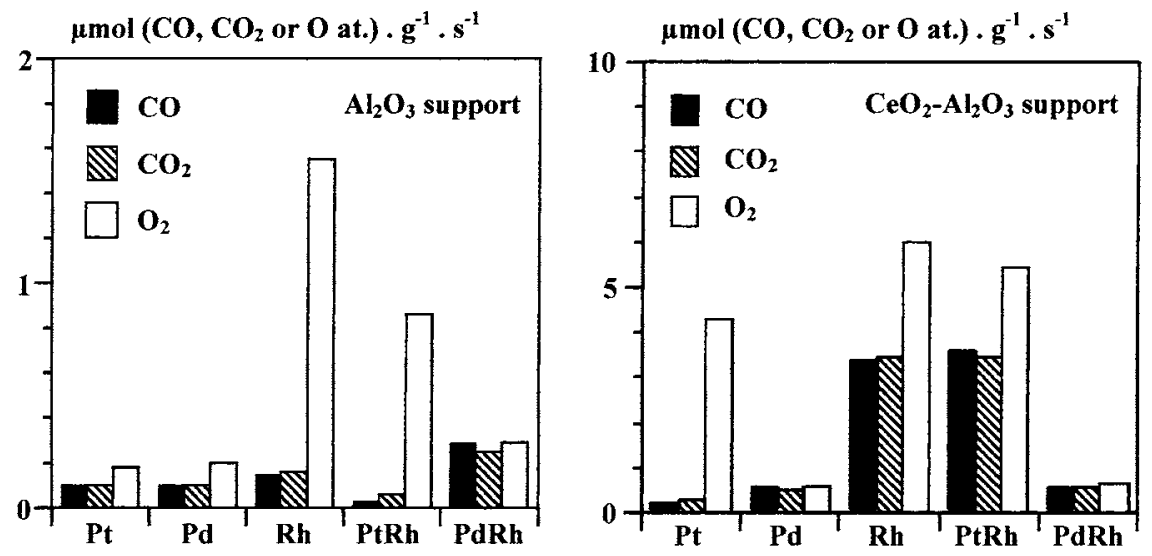

Fig. 6. Comparison of the initial rates for $\mathrm{CO}$ consumption and $\mathrm{CO}_{2}$ formation during $\mathrm{CO}$ step and for $\mathrm{O}_{2}$ consumption during $\mathrm{O}_{2}$ step on alumina (A) and ceria-alumina (CA) supported catalysts at $450^{\circ} \mathrm{C}$.
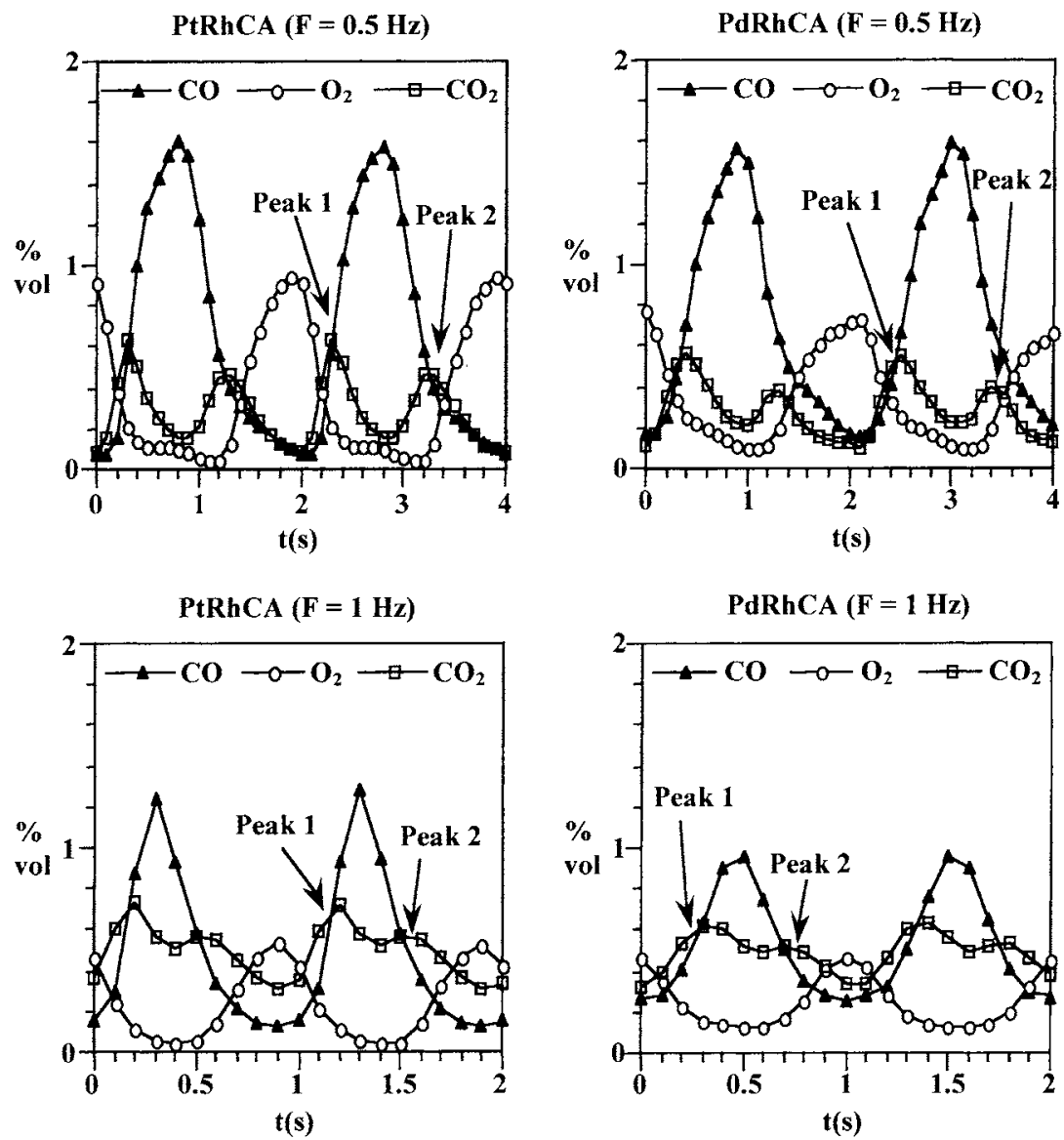

Fig. 7. Evolution of reactants $\left(\mathrm{CO}\right.$ and $\left.\mathrm{O}_{2}\right)$ and product $\left(\mathrm{CO}_{2}\right)$ upon reaction at $450^{\circ} \mathrm{C}$ under transient conditions $(F=0.5$ and $1 \mathrm{~Hz})$ on bimetallic $\mathrm{PtRh} / \mathrm{CeO}_{2}-\mathrm{Al}_{2} \mathrm{O}_{3}$ (PtRhCA) and $\mathrm{PdRh} / \mathrm{CeO}_{2}-\mathrm{Al}_{2} \mathrm{O}_{3}$ (PdRhCA) catalysts. 
conditions. Alternate $2 \% \mathrm{CO}$ or $1 \% \mathrm{O}_{2}$ pulses are injected on the catalyst at a frequency of 1 or $0.5 \mathrm{~Hz}$ for 10 min (step (i), see Fig. 1). To understand what follows, one must keep in mind that, at every gas change, both gases $\left(\mathrm{CO}\right.$ and $\left.\mathrm{O}_{2}\right)$ coexist in the gas phase for a fraction of a second. In those conditions, $\mathrm{CO}$ catalytic oxidation with gaseous oxygen may occur $\left(\mathrm{CO}_{2 \text { ox }}\right)$. Looking at $\mathrm{CO}_{2}$ formation, one will have to make the difference between $\mathrm{CO}_{2}$ originating from the $\mathrm{CO}$ catalytic oxidation using gaseous oxygen $\left(\mathrm{CO}_{2}\right.$ ox $)$ and $\mathrm{CO}_{2}$ coming from the reverse oxygen storage reaction $\left(\mathrm{CO}_{2}\right.$ OSC $)$.

In all cases, $\mathrm{CO}_{2}$ formation occurs after every gas change. One $\mathrm{CO}_{2}$ formation peak $\left(\mathrm{CO}_{2}(1)\right)$ appears going from $\mathrm{O}_{2}$ to $\mathrm{CO}$ (peak 1, see Fig. 7). In this case the catalyst is partially oxidized before the introduction of $\mathrm{CO}$. This $\mathrm{CO}_{2}$ formation peak includes $\mathrm{CO}_{2}$ coming from both the catalytic oxidation of $\mathrm{CO}$ in the presence of gaseous oxygen $\left(\mathrm{CO}_{2 \text { ox(1) }}\right)$ and the oxygen storage reverse reaction $\left(\mathrm{CO}_{2}(1)=\mathrm{CO}_{2 \text { ox(1) }}+\right.$ $\mathrm{CO}_{2}$ OSC $)$. The second $\mathrm{CO}_{2}$ formation peak $\left(\mathrm{CO}_{2}(2)\right)$ forms when $\mathrm{CO}$ is replaced by $\mathrm{O}_{2}$ in the gas feed (peak 2, see Fig. 7). In that case, the catalyst is partially reduced. Here, the only reaction responsible for the formation of $\mathrm{CO}_{2}$ is the catalytic oxidation of $\mathrm{CO}$ $\left(\mathrm{CO}_{2}(2)=\mathrm{CO}_{2 \text { ox (2) })}\right)$ : upon step change from 0 to $1 \%$ $\mathrm{O}_{2}$ (step (v), see Fig. 1) practically no $\mathrm{CO}_{2}$ evolution was observed. These observations indicate that $\mathrm{CO}$ oxidation kinetics are governed by the catalyst state: oxidized or reduced. In fact, $\mathrm{CO}_{2}$ formation related to the oxygen storage process $\left(\mathrm{CO}_{2} \mathrm{OSC}\right)$ only occurs on the oxidized catalyst when $\mathrm{O}_{2}$ is replaced by $\mathrm{CO}$ (peak 1). In the course of a switch from $\mathrm{CO}$ to $\mathrm{O}_{2}$, oxygen storage occurs: an oxygen uptake is observed but no $\mathrm{CO}_{2}$ forms. Furthermore, we may see from Tables $4-7$ that $\mathrm{CO}_{2 \text { ox(1) }} \neq \mathrm{CO}_{2 \text { ox(2) }}$.

Examples are given in Fig. 7 for $\mathrm{PtRh} / \mathrm{CeO}_{2}-\mathrm{Al}_{2} \mathrm{O}_{3}$ (PtRhCA) and $\mathrm{PdRh} / \mathrm{CeO}_{2}-\mathrm{Al}_{2} \mathrm{O}_{3}$ (PdRhCA). The evolution of the gas phase composition $\left(\mathrm{CO}, \mathrm{O}_{2}\right.$ and $\mathrm{CO}_{2}$ ) at the reactor outlet is presented as a function of time. One can see that an increase of the alternating frequency does not modify the qualitative results. The resolution between peak $1\left(\mathrm{CO}_{2}(1)\right)$ and peak $2\left(\mathrm{CO}_{2}(2)\right)$ is just harder in some cases, when the reactivity of the catalyst is high. For comparison, the evolution of $\mathrm{CO}_{2}$ formation as a function of time is presented in Fig. 8 for Pd-based catalysts (series 2) and in Fig. 9 for Pt-based catalysts (series 1).

Quantitative information may be obtained from the integration of the $\mathrm{CO}, \mathrm{O}_{2}$ and $\mathrm{CO}_{2}$ profiles. In the case of $\mathrm{CO}_{2}$ formation, the so-called peaks 1 and 2 were integrated separately. To calculate the total amount of $\mathrm{CO}_{2}$ produced from the $\mathrm{CO}$ catalytic oxidation $\left(\mathrm{CO}_{2}\right.$ catalytic $)$, the amount of $\mathrm{CO}_{2}$ originating from the reverse oxygen storage reaction must be subtracted from peak $1\left(\mathrm{CO}_{2}(1)\right)$. For that purpose, OSC values $\left(\mathrm{OSC}_{\text {step }}\right)$ were estimated from the data acquired in the course of step (iii) (see Fig. 1) in the second part of the experiment (CO step). To compare values after the same contact time, $\mathrm{OSC}_{\text {step }}$ was taken to be

Table 4

Determination of the different contributions to the $\mathrm{CO}_{2}$ formation $\left(\mathrm{CO}_{2}(1), \mathrm{CO}_{2}(2)\right.$ and $\mathrm{CO}_{2}$ catalytic $)$ from the total amount $\mathrm{CO}$ and $\mathrm{O}_{2}$ consumed $\left(\mathrm{CO}\right.$ and $\left.\mathrm{O}_{2}\right)$ and the total amount of $\mathrm{CO}_{2}$ formed $\left(\mathrm{CO}_{2}\right)$ during one period of time $(1 \mathrm{~s})$ under transient conditions at $450^{\circ} \mathrm{C}$ for series 1 samples $^{\mathrm{a}}$

\begin{tabular}{|c|c|c|c|c|c|c|c|}
\hline Catalyst & $\mathrm{CO}^{\mathrm{b}}$ & $\mathrm{O}_{2}^{\mathrm{b}}$ & $\mathrm{CO}_{2}{ }^{\mathrm{b}}$ & $\mathrm{OSC}_{\text {step }}{ }^{\mathrm{c}}$ & $\mathrm{CO}_{2}(1)^{\mathrm{d}}$ & $\mathrm{CO}_{2}(2)^{\mathrm{e}}$ & $\mathrm{CO}_{2 \text { catalytic }}{ }^{\mathrm{f}}$ \\
\hline PtA & 16.5 & 15.8 & 15.3 & 0.1 & 7.5 & 7.9 & 15.3 \\
\hline $\mathrm{RhA}$ & 17.2 & 16.6 & 16.7 & 0.3 & 8.6 & 8.1 & 16.4 \\
\hline PtRhA & 19.1 & 18 & 17.4 & 0.3 & 8.4 & 9.0 & 17.1 \\
\hline PtCA & 16.8 & 15.8 & 15.4 & 0.3 & 7.3 & 8.1 & 15.1 \\
\hline PtRhCA & 17.8 & 17.6 & 16.7 & 2.4 & 9.2 & 7.6 & 14.4 \\
\hline RhCA & 24.8 & 24.8 & 23.9 & 3.5 & -g & -g & 20.4 \\
\hline
\end{tabular}

\footnotetext{
${ }^{a}$ Bimetallic PtRh-based alumina (A) and ceria-alumina (CA) supported catalysts.

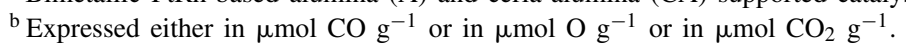

${ }^{\mathrm{c}}$ Determined from stationary regime measurements: $\mathrm{OSC}_{\text {step }}=Q_{0.5}$ (see Table 3).

${ }^{\mathrm{d}}$ Determined from the integration of peak 1 .

${ }^{\mathrm{e}}$ Determined from the integration of peak 2 .

${ }^{\mathrm{f}} \mathrm{CO}_{2 \text { catalytic }}=\left(\mathrm{CO}_{2}(1)-\mathrm{OSC}_{\text {step }}\right)+\mathrm{CO}_{2}(2)$.

${ }^{\mathrm{g}}$ Peaks could not be differentiated.
} 
Table 5

Determination of the different contributions to the $\mathrm{CO}_{2}$ formation $\left(\mathrm{CO}_{2}(1), \mathrm{CO}_{2}(2)\right.$ and $\mathrm{CO}_{2}$ catalytic $)$ from the total amount of $\mathrm{CO}$ and $\mathrm{O}_{2}$ consumed $\left(\mathrm{CO}\right.$ and $\left.\mathrm{O}_{2}\right)$ and the total amount of $\mathrm{CO}_{2}$ formed $\left(\mathrm{CO}_{2}\right)$ during one period of time $(2 \mathrm{~s})$ under transient conditions at $450^{\circ} \mathrm{C}$ for series 1 samples $^{\mathrm{a}}$

\begin{tabular}{|c|c|c|c|c|c|c|c|}
\hline Catalyst & $\mathrm{CO}^{\mathrm{b}}$ & $\mathrm{O}_{2}{ }^{\mathrm{b}}$ & $\mathrm{CO}_{2}{ }^{\mathrm{b}}$ & OSC $_{\text {step }}{ }^{c}$ & $\mathrm{CO}_{2}(1)^{\mathrm{d}}$ & $\mathrm{CO}_{2}(2)^{\mathrm{e}}$ & $\mathrm{CO}_{2 \text { catalytic }} \mathrm{f}^{\mathrm{f}}$ \\
\hline PtA & 16.1 & 16.4 & 15.6 & 0.2 & 6.6 & 9.1 & 15.5 \\
\hline RhA & 19.3 & 18.8 & 18.3 & 0.6 & 9.7 & 8.5 & 17.6 \\
\hline PtRhA & 19.1 & 24.2 & 19.1 & 0.6 & 8.4 & 10.7 & 18.5 \\
\hline PtCA & 19.6 & 20.0 & 19.0 & 0.7 & 8.3 & 10.7 & 18.3 \\
\hline PtRhCA & 20.0 & 19.8 & 19.4 & 5.2 & 9.8 & 9.5 & 14.1 \\
\hline $\mathrm{RhCA}$ & 25.9 & 26.2 & 25.3 & 7.9 & 13.6 & 11.7 & 17.4 \\
\hline
\end{tabular}

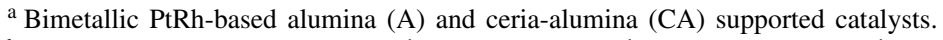

${ }^{\mathrm{b}}$ Expressed either in $\mu \mathrm{mol} \mathrm{CO} \mathrm{g}{ }^{-1}$ or in $\mu \mathrm{mol} \mathrm{O} \mathrm{g}{ }^{-1}$ or in $\mu \mathrm{mol} \mathrm{CO}_{2} \mathrm{~g}^{-1}$.

${ }^{\mathrm{c}}$ Determined from stationary regime measurements: $\mathrm{OSC}_{\text {step }}=Q_{1}$ (see Table 3).

${ }^{\mathrm{d}}$ Determined from the integration of peak 1.

${ }^{\mathrm{e}}$ Determined from the integration of peak 2.

${ }^{\mathrm{f}} \mathrm{CO}_{2 \text { catalytic }}=\left(\mathrm{CO}_{2}(1)-\mathrm{OSC}_{\text {step }}\right)+\mathrm{CO}_{2}(2)$.

Table 6

Determination of the different contributions to the $\mathrm{CO}_{2}$ formation $\left(\mathrm{CO}_{2}(1), \mathrm{CO}_{2}(2)\right.$ and $\mathrm{CO}_{2 \text { catalytic }}$ ) from the total amount $\mathrm{CO}$ and $\mathrm{O}_{2}$ consumed $\left(\mathrm{CO}\right.$ and $\left.\mathrm{O}_{2}\right)$ and the total amount of $\mathrm{CO}_{2}$ formed $\left(\mathrm{CO}_{2}\right)$ during one period of time $(1 \mathrm{~s})$ under transient conditions at $450^{\circ} \mathrm{C}$ for series 2 samples $^{\mathrm{a}}$

\begin{tabular}{llllllll}
\hline Catalyst & $\mathrm{CO}^{\mathrm{b}}$ & $\mathrm{O}_{2}{ }^{\mathrm{b}}$ & $\mathrm{CO}_{2}{ }^{\mathrm{b}}$ & $\mathrm{OSC}_{\text {step }}{ }^{\mathrm{c}}$ & $\mathrm{CO}_{2}(1)^{\mathrm{d}}$ & $\mathrm{CO}_{2}(2)^{\mathrm{e}}$ & $\mathrm{CO}_{2 \text { catalytic }}{ }^{\mathrm{f}}$ \\
\hline PdA & 14.0 & 14.2 & 13.7 & 0.2 & 7.3 & 6.4 & 13.5 \\
PdCA & 14.4 & 13.9 & 13.7 & 0.8 & 7.4 & 6.3 & 12.9 \\
PdRhA & 14.7 & 14.2 & 14.0 & 0.2 & 8.4 & 5.6 & 13.8 \\
PdRhCA & 16.6 & 17.0 & 16.6 & 1.1 & 9.6 & 7.0 & 15.5 \\
\hline
\end{tabular}

${ }^{\text {a }}$ Bimetallic PdRh-based alumina (A) and ceria-alumina (CA) supported catalysts.

${ }^{\mathrm{b}}$ Expressed either in $\mu \mathrm{mol} \mathrm{CO} \mathrm{g}{ }^{-1}$ or in $\mu \mathrm{mol} \mathrm{O} \mathrm{g}-1$ or in $\mu \mathrm{mol} \mathrm{CO}_{2} \mathrm{~g}^{-1}$.

${ }^{\mathrm{c}}$ Determined from stationary regime measurements: $\mathrm{OSC}_{\text {step }}=Q_{0.5}$ (see Table 3).

${ }^{\mathrm{d}}$ Determined from the integration of peak 1.

${ }^{\mathrm{e}}$ Determined from the integration of peak 2.

${ }^{\mathrm{f}} \mathrm{CO}_{2 \text { catalytic }}=\left(\mathrm{CO}_{2}(1)-\mathrm{OSC}_{\text {step }}\right)+\mathrm{CO}_{2}(2)$.

Table 7

Determination of the different contributions to the $\mathrm{CO}_{2}$ formation $\left(\mathrm{CO}_{2}(1), \mathrm{CO}_{2}(2)\right.$ and $\mathrm{CO}_{2}$ catalytic $)$ from the total amount of $\mathrm{CO}$ and $\mathrm{O}_{2}$ consumed $\left(\mathrm{CO}\right.$ and $\left.\mathrm{O}_{2}\right)$ and the total amount of $\mathrm{CO}_{2}$ formed $\left(\mathrm{CO}_{2}\right)$ during one period of time $(2 \mathrm{~s})$ under transient conditions at $450^{\circ} \mathrm{C}$ for series 2 samples $^{\mathrm{a}}$

\begin{tabular}{lllllclc}
\hline Catalyst & $\mathrm{CO}^{\mathrm{b}}$ & $\mathrm{O}_{2}{ }^{\mathrm{b}}$ & $\mathrm{CO}_{2}{ }^{\mathrm{b}}$ & $\mathrm{OSC}_{\text {step }}{ }^{\mathrm{c}}$ & $\mathrm{CO}_{2}(1)^{\mathrm{d}}$ & $\mathrm{CO}_{2}(2)^{\mathrm{e}}$ & $\mathrm{CO}_{2 \text { catalytic }}{ }^{\mathrm{e}}$ \\
\hline PdA & 15.5 & 16.2 & 15.4 & 0.3 & 8.4 & 7.0 & 15.1 \\
PdCA & 18.1 & 18.6 & 17.8 & 1.7 & 8.1 & 7.9 & 16.3 \\
PdRhA & 15.6 & 15.6 & 15.4 & 0.4 & 10.9 & 6.6 & 15.1 \\
PdRhCA & 20.0 & 20.0 & 19.8 & 2.6 & 10.9 & 8.9 & 17.2
\end{tabular}

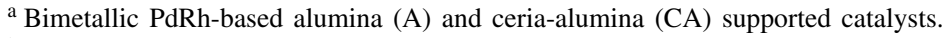

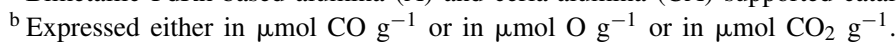

${ }^{\mathrm{c}}$ Determined from stationary regime measurements: $\mathrm{OSC}_{\text {step }}=Q_{1}$ (see Table 3).

${ }^{\mathrm{d}}$ Determined from the integration of peak 1 .

e Determined from the integration of peak 2.

${ }^{\mathrm{f}} \mathrm{CO}_{2 \text { catalytic }}=\left(\mathrm{CO}_{2}(1)-\mathrm{OSC}_{\text {step }}\right)+\mathrm{CO}_{2}(2)$. 

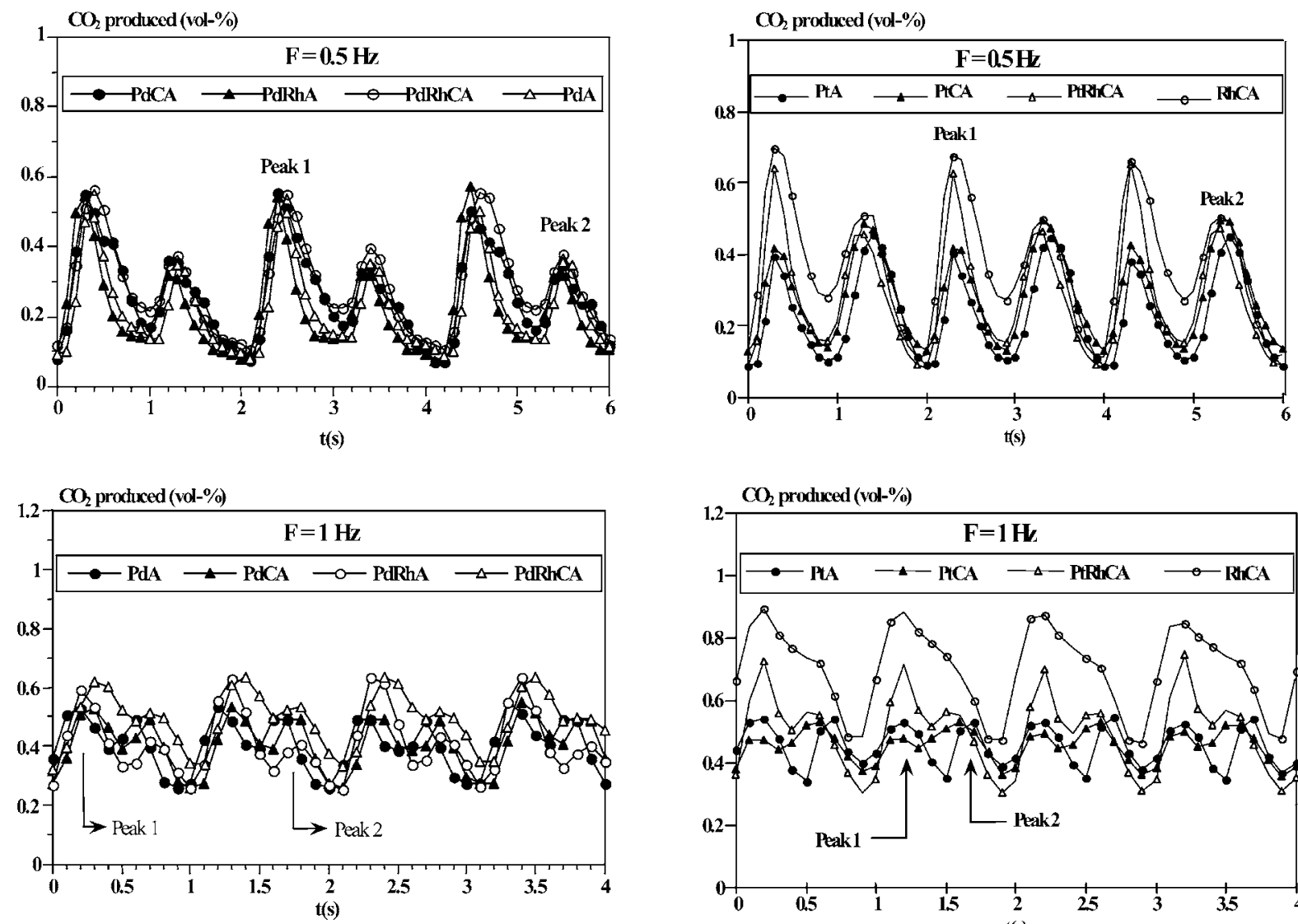

Fig. 8. Evolution of $\mathrm{CO}_{2}$ produced under transient conditions $(F=0.5$ and $1 \mathrm{~Hz})$ upon reaction at $450^{\circ} \mathrm{C}$ on Pd-based alumina (A) and ceria-alumina (CA) supported catalysts.

equal to the cumulated amount of $\mathrm{CO}_{2}$ produced after half a period of time. For example, in the case of experiments performed at $0.5 \mathrm{~Hz}, \mathrm{OSC}_{\text {step }}$ is given by the integrated amount of $\mathrm{CO}_{2}$ produced after $1 \mathrm{~s}$. The average value of the calculated amounts of $\mathrm{CO}$ and $\mathrm{O}_{2}$ consumed and $\mathrm{CO}_{2}$ produced during one period of time ( 1 or $2 \mathrm{~s}$ ) are displayed in Tables 4 and 5 for Pt, $\mathrm{Rh}$ and PtRh catalysts (series 1) and in Tables 6 and 7 for Pd-based catalysts (series 2).

From all those results we could conclude that (i) mass balance is complete and no carbon is left over the surface and (ii) oxygen storage is more sensitive to the catalyst state than the catalytic $\mathrm{CO}$ oxidation reaction. In fact, OSC depends on both the number and the nature of the active sites. In that case, the nature of the metal (Pt, $\mathrm{Pd}$ or $\mathrm{Rh})$ as well as the support

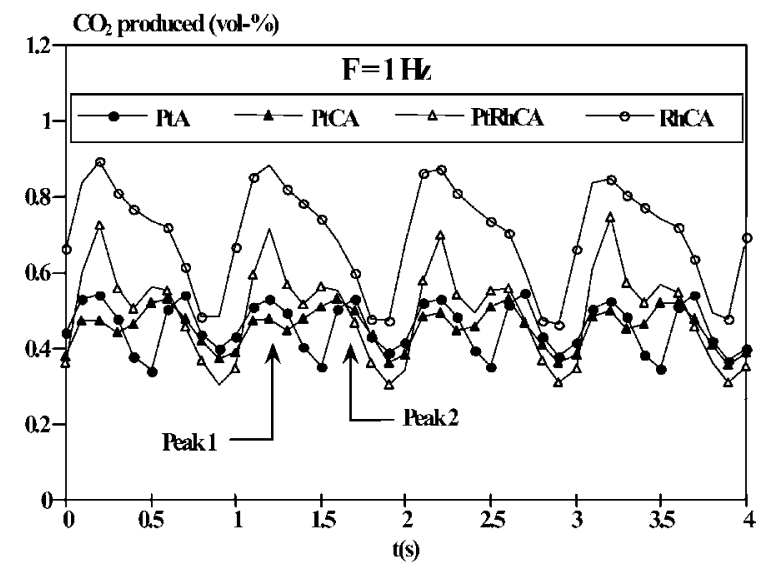

Fig. 9. Evolution of $\mathrm{CO}_{2}$ produced under transient conditions ( $F=0.5$ and $1 \mathrm{~Hz}$ ) upon reaction at $450^{\circ} \mathrm{C}$ on Pt-based alumina (A) and ceria-alumina (CA) supported catalysts.

(alumina or ceria-alumina) are important factors. On the opposite, in the case of the $\mathrm{CO}+\mathrm{O}_{2}$ catalytic reaction, oxygen essentially comes from the gas phase. Thus, even if the catalyst has a low OSC, it will be, however, continuously fed with oxygen and the reaction may still proceed. At $450^{\circ} \mathrm{C}$ this reaction is fast. Moreover, the activation energy for the catalytic $\mathrm{CO}$ oxidation reaction was found to vary between 80 and $130 \mathrm{~kJ} \mathrm{~mol}^{-1}[24,25]$. Nevertheless, the activity stays high even for strongly aged catalysts.

Looking at $\mathrm{OSC}$ values $\left(\mathrm{OSC}_{\text {step }}\right)$, catalysts may be classified in descending order as follows: $\mathrm{Rh} / \mathrm{CeO}_{2}$ $\mathrm{Al}_{2} \mathrm{O}_{3}(\mathrm{RhCA})>\mathrm{PtRh} / \mathrm{CeO}_{2}-\mathrm{Al}_{2} \mathrm{O}_{3}(\mathrm{PtRhCA})>$ $\mathrm{PdRh} / \mathrm{CeO}_{2}-\mathrm{Al}_{2} \mathrm{O}_{3}$ (PdRhCA) $>\mathrm{Pd} / \mathrm{CeO}_{2}-\mathrm{Al}_{2} \mathrm{O}_{3}$ $(\mathrm{PdCA})>\mathrm{Pt} / \mathrm{CeO}_{2}-\mathrm{Al}_{2} \mathrm{O}_{3}(\mathrm{PtCA})>\mathrm{Rh} / \mathrm{Al}_{2} \mathrm{O}_{3}$ 
$(\mathrm{RhA}) \cong \mathrm{PtRh} / \mathrm{Al}_{2} \mathrm{O}_{3}(\mathrm{PtRhA})>\mathrm{PdRh} / \mathrm{Al}_{2} \mathrm{O}_{3}$ $(\mathrm{PdRhA})>\mathrm{Pt} / \mathrm{Al}_{2} \mathrm{O}_{3}(\mathrm{PtA}) \cong \mathrm{Pd} / \mathrm{Al}_{2} \mathrm{O}_{3}(\mathrm{PdA})$. Relative reactivities could be explained both by the introduction of ceria on the alumina support or by the substitution of $\mathrm{Rh}$ particles to $\mathrm{Pt}$ or Pd particles. The presence of ceria would induce a new reaction pathway through a bifunctional mechanism. $\mathrm{CO}_{2}$ formation would derive from the reaction between an adsorbed $\mathrm{CO}$ molecule on the metal surface and an oxygen atom coming from the ceria surface in the vicinity of the metal particles. As a result, cerium oxide would reduce deactivation effects related to metal sintering.

Furthermore, at $450^{\circ} \mathrm{C}, \mathrm{Rh}$-based catalysts are more active than Pt- and Pd-based catalysts. The activity of the aged Rh-based catalysts would derive from both a high stability of $\mathrm{Rh}_{2} \mathrm{O}_{3}$ particles towards sintering compared to $\mathrm{PtO}_{2}$ and $\mathrm{PdO}$ [8] and a better oxygen transfer from $\mathrm{CeO}_{2}$ to $\mathrm{Rh}[7,26]$.

Additionally, a comparison between the amounts of $\mathrm{CO}_{2}$ produced on $\mathrm{Pt} / \mathrm{Al}_{2} \mathrm{O}_{3}(\mathrm{PtA})$ and $\mathrm{Pt} / \mathrm{CeO}_{2}-\mathrm{Al}_{2} \mathrm{O}_{3}$ (PtCA) catalysts in the course of step (i) (see Fig. 1), going from $\mathrm{O}_{2}$ to $\mathrm{CO}$ (peak 1) and vice versa (peak 2), shows that $\mathrm{CO}_{2}(2)$ is slightly larger than $\mathrm{CO}_{2}(1)$ (Tables 4 and 5). This observation confirms that the OSC of these two catalysts must be very low. In fact, if the OSC were high, $\mathrm{CO}_{2}(1)$ would be much larger than $\mathrm{CO}_{2}$ (2). In these two cases, $\mathrm{CO}_{2}$ essentially originates from the $\mathrm{CO}$ oxidation catalytic reaction. Moreover, considering that $\mathrm{CO}_{2}(2)$ is slightly larger than $\mathrm{CO}_{2}(1)$, one can conclude that $\mathrm{CO}$ catalytic oxidation is faster on a reduced catalyst than on a partially pre-oxidized catalyst. These two different behaviors could be related to the electronic configuration of Pt. Electronic configuration of reduced platinum may be written [Xe] $\mathrm{f}^{14} 5 \mathrm{~d}^{9} 6 \mathrm{~s}^{1}$. Both $\mathrm{d}$ and $\mathrm{s}$ orbitals are not fully occupied and electronic transfers may occur. Platinum oxide (PtO) has a $[\mathrm{Xe}] \mathrm{f}^{14} 5 \mathrm{~d}^{10} 6 \mathrm{~s}^{2}$ electronic configuration. The $\mathrm{d}$ and $\mathrm{s}$ orbitals are fully occupied and electronic transfer may hardly take place. This would explain the better activity of reduced catalysts compared to oxidized catalysts.

In the case of the bimetallic PtRh-based catalysts (series 1), OSC is much higher. $\mathrm{CO}_{2}(1)$ is then larger than $\mathrm{CO}_{2}(2)$ and the whole amount of $\mathrm{CO}_{2}$ produced mainly originates from the oxygen storage reverse reaction. If the contribution of the OSC to peak 1 is subtracted, peak 2 becomes larger than peak 1. This situation is the same as for Pt catalysts. For Pd catalysts, the opposite is observed. Oxidized Pd catalysts are slightly more active than the reduced ones.

This difference between $\mathrm{CO}_{2}(1)$ and $\mathrm{CO}_{2}(2)$ is even more pronounced when experiments are carried out at $F=0.5 \mathrm{~Hz}$. At $F=0.5 \mathrm{~Hz}, \mathrm{CO}$ or $\mathrm{O}_{2}$ injections length are too short and the catalyst does not fully reduce or oxidize.

Finally, looking at the global catalytic activity of these catalysts, one can conclude that Pt catalysts are less sensitive to frequency than Pd catalysts. It is clear from Tables 6 and 7 that Pd-based catalysts (series 2) are more active in the $\mathrm{CO}$ catalytic oxidation when experiments are carried out at a lower frequency. This observation could indicate that Pt-based catalysts (series 1) would be more reactive, with faster response time.

\section{Conclusions}

Our experimental setup was shown to be appropriate for the measurement of both the OSC under transient conditions and the reactivity in the $\mathrm{CO}$ catalytic oxidation reaction of any catalyst. For the first time, OSC could be measured under dynamic conditions with alternate $\mathrm{CO}$ and $\mathrm{O}_{2}$ pulses at frequency up to $1 \mathrm{~Hz}$.

This study showed that $\mathrm{CO}_{2}$ formation occurs after every modification in the gas phase composition. $\mathrm{CO}_{2}$ may form on a pre-oxidized catalyst when $\mathrm{O}_{2}$ is replaced by $\mathrm{CO}$. In that case, both OSC and $\mathrm{CO}$ catalytic oxidation participate to $\mathrm{CO}_{2}$ formation. Second, $\mathrm{CO}_{2}$ is also produced on a pre-reduced catalysts when $\mathrm{O}_{2}$ replaces $\mathrm{CO}$. In that case, $\mathrm{CO}_{2}$ exclusively originates from $\mathrm{CO}$ catalytic oxidation.

At $450^{\circ} \mathrm{C}$, catalysts reactivity in the catalytic oxidation of $\mathrm{CO}$ was shown to slightly depend on the metal nature. On the opposite, OSC strongly depends on the catalysts state - oxidized or reduced. Considering the OSC value, a combination of $\mathrm{Rh}$ and ceria appeared to be the optimum among the catalysts under study. Relative activities were analyzed on the basis of the metal oxides relative stability and the metals electronic configuration.

Furthermore, in all cases, catalysts reduction rates under $\mathrm{CO}$ were shown to be smaller than the reoxidation rates under $\mathrm{O}_{2}$. An optimized catalyst would have to have an enhance reducibility. 


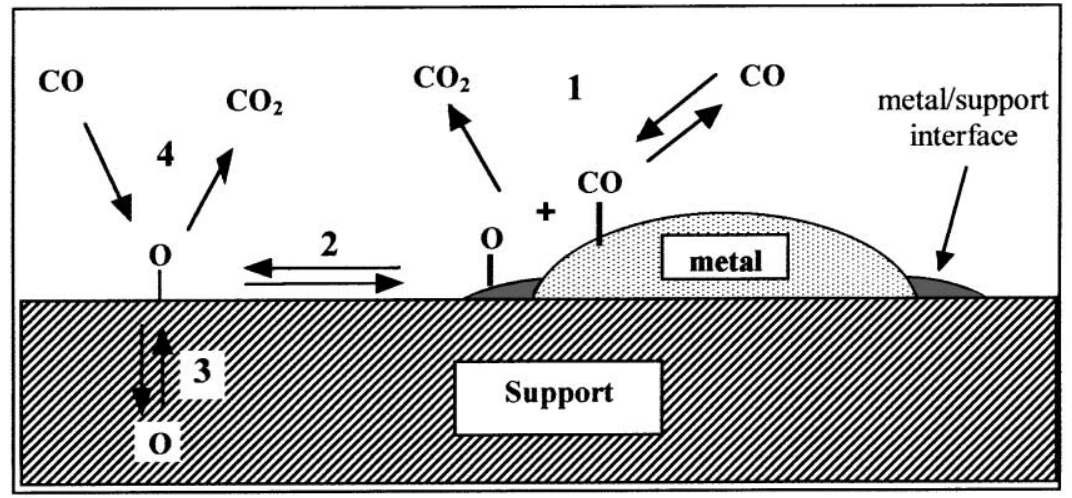

Fig. 10. Schematic representation of all processes potentially involved during OSC measurements.

Finally, based on all these observations, a general scheme of the oxygen storage process is presented in Fig. 10. CO would be activated on the metal surface and react with oxygen atoms coming from the oxide support. Oxygen transfer from the support to the metal surface would depend on both oxygen mobility at the surface (2) and in the bulk of the oxide (3) and on the metal/support interface. $\mathrm{CO}$ direct oxidation on the support is assumed to be very low.

\section{References}

[1] H.C. Yao, Y.F. Yu Yao, J. Catal. 86 (1984) 254.

[2] E.C. Su, C.N. Montreuil, W.G. Rothschild, Appl. Catal. 17 (1985) 75.

[3] E.C. Su, W.G. Rothschild, J. Catal. 99 (1986) 506.

[4] B. Engler, E. Koberstein, P. Schubert, Appl. Catal. 48 (1989) 71.

[5] P. Lööf, B. Kasemo, K.-E. Keck, J. Catal. 118 (1989) 339.

[6] T. Miki, T. Ogawa, M. Haneda, N. Kakuta, A. Ueno, S. Tateishi, S. Matsuuta, M. Sato, J. Phys. Chem. 94 (1990) 6464.

[7] D. Martin, R. Taha, D. Duprez, Stud. Surf. Sci. Catal. 96 (1994) 801.

[8] S. Kacimi, J. Barbier Jr., J.R. Taha, D. Duprez, Catal. Lett. 22 (1993) 343.
[9] J.-P. Cuif, G. Blanchard, O. Touret, M. Marczi, E. Quemere, SAE Technical Paper Series 961906, 1996.

[10] W.B. Clemmens, M.A. Sabourin, T. Rao, SAE Technical Paper Series 900062, 1990.

[11] J.R. Theis, SAE Technical Paper Series 961900, 1996.

[12] R. Taha, D. Duprez, N. Mouaddib-Moral, C. Gauthier, Stud. Surf. Sci. Catal. 116 (1998) 549.

[13] M. Sideris (Ed.), Methods for Monitoring and Diagnosing the Efficiency of Catalytic Converters. A Patent-oriented Survey, Studies in Surface Science and Catalysis, Vol. 115, Elsevier, Amsterdam, 1998.

[14] T. Maunula, A. Vakkilainen, A. Lievonen, K. Torkkell, K. Niskanen, M. Harkonen, SAE Technical Paper Series 993625, 1999.

[15] S. Kacimi, D. Duprez, Stud. Surf. Sci. Catal. 71 (1991) 581.

[16] R. Taha, Ph.D. thesis, Université de Poitiers, 1994.

[17] D. Martin, Ph.D. thesis, Université de Poitiers, 1994.

[18] D. Martin, R. Taha, D. Duprez, Stud. Surf. Sci. Catal. 96 (1995) 801.

[19] R. Taha, D. Duprez, Catal. Lett. 14 (1992) 51.

[20] R. Taha, D. Duprez, J. Chim. Phys. 92 (1995) 1506.

[21] E. Ruckenstein, B. Pulvermarcher, J. Catal. 38 (1977) 73.

[22] P.C. Flynn, S.E. Wanke, J. Catal. 34 (1974) 310.

[23] C.H. Bartholomew, Appl. Catal. A: Gen. 107 (1993) 1.

[24] Y.-F. Yu Yao, J. Catal. 87 (1984) 152.

[25] Y.-F. Yu Yao, Ind. Eng. Chem. Prod. Res. Dev. 19 (1980) 293.

[26] R. Taha, D. Martin, S. Kacimi, D. Duprez, Catal. Today 29 (1996) 89. 